\title{
Japanese quince (Chaenomeles japonica L.) fruit polyphenolic extract modulates carbohydrate metabolism in HepG2 cells via AMP-activated protein kinase
}

\author{
Małgorzata Zakłos-Szyda $\bowtie$ and Nina Pawlik \\ Faculty of Biotechnology and Food Sciences, Lodz University of Technology, Institute of Technical Biochemistry, Łódź, Poland
}

\begin{abstract}
Type 2 diabetes mellitus (T2D) is a chronic diet-related disease which due to many dangerous complications has become a prominent health problem of the world. The aim of the study was to explore the in vitro activity of Japanese quince (Chaenomeles japonica L., family Rosaceae, JQ) fruit polyphenolic extract as modulator of carbohydrates metabolism. The research was designed to investigate the effect of JQ polyphenolic extract on glucose metabolism in human hepatoma HepG2 cell line cultured under normal non-metabolically changed and hyperglycemic conditions. Pretreatment of the cells with JQ preparation caused decrease of intracellular ROS generation and influenced mitochondrial membrane polarization which seemed to lead to AMPK activation. Further effects observed in HepG2 cells were associated with activation of the enzyme: elevation of glucose uptake and glycogen content, and alleviation of gluconeogenesis through modulation of PEPCK, PTP1B, FOXO1 and GLUT2/4 expression. These findings suggest that JQ polyphenols exhibit hypoglycemic effects via modulation of AMPK signaling in hepatocytes.
\end{abstract}

Key words: AMPK, diabetes, glucose metabolism, HepG2, Japanese quince, polyphenols

Received: 05 May, 2017; revised: 04 December, 2017; accepted: 11 December, 2017; available on-line: 01 March, 2018

e-mail: malgorzata.zaklos-szyda@p.lodz.pl

Abbreviations: AMPK, AMP-activated protein kinase; EGCG, epigallocatechin-3-gallate; FOXO1, forkhead transcription factor box G1; GLUT4, glucose transporter 4; GSK-3, glycogen synthase kinase-3; GYS2, liver glycogen synthase; G6PC, glucose-6-phosphatase; IR, insulin receptor; IRS1/2, insulin receptor substrate $1 / 2$; PEPCK, phosphoenolpyruvate carboxykinase; PGC-1alpha, peroxisome proliferative activated receptor-gamma co-activator; PTP1B, protein tyrosine phosphatase $1 \mathrm{~B}$; ROS, reactive oxygen species; T2D, type 2 diabetes mellitus

\section{INTRODUCTION}

Epidemiological data show that diet-related chronic diseases have become a prominent health problem of the world. According to World Health Organization in 2014 about $8.5 \%$ of the world's adult population suffered from diabetes and almost $90 \%$ of diabetes cases belong to type 2 diabetes (T2D), which is considered the major diet-re lated cause of human deaths (2016). T2D is characterized mainly by hyperglycemia, hyperlipidemia and elevated hepatic glucose production that result from irregularities in the insulin secretion, attenuated insulin sensitivity (due to decreased glucose uptake by peripheral tissues) and pancreatic beta cells dysfunction caused by multiple stimuli including glucotoxicity, lipo- toxicity, proinflammatory cytokines and oxidative stress (Brereton et al., 2016). A lot of research revealed that T2D development is preceded by elevated, non-diabetic levels of blood glucose, termed as prediabetes or prediabetic dysglycemia (Hostalek et al., 2015; Kerimi et al., 2015). Recent clinical studies demonstrated that prediabetes can be delayed due to the lifestyle improvement, mainly through physical activity and diet enriched with bioactive compounds that can affect the key molecular targets of metabolism. One of the most important regulators of lipid and glucose metabolism is a 5'-adenosine monophosphate-activated protein kinase (AMP-activated protein kinase or AMPK), which is expressed predominantly in the liver, brain, skeletal muscle and adipose tissues (Hardie, 2014). It is known as a sensor of energy status that maintains cellular energy homeostasis and, therefore, it is regarded as potential therapeutic target for the prevention and treatment of diabetes (Hardie, 2016; Hardie, 2011). AMPK is activated under metabolic stress conditions when ATP consumption accelerates and AMP:ATP ratio increases. The protein kinase is a heterotrimer containing $\alpha$ catalytic subunit and two regulatory subunits $(\beta$ and $\gamma)$. During the enzyme activation AMP (mainly) and ADP (to some extent) directly bind to Bateman domains in $\gamma$ subunit, leading to a conformational change that inhibits dephosphorylation of Thr172 by protein phosphatases and strongly increases the enzyme activity (Hardie, 2011). Another factor determining the enzyme activation is its phosphorylation at $\alpha$ Thr172 and this process can be catalyzed by three upstream kinases: tumor-suppressor liver kinase B1(LKB1), calcium-dependent calcium/calmodulin-dependent protein kinase kinase $\beta$ (CaMKK $\beta)$ or transforming growth factor- $\beta$ activated protein kinase-1 (TAK1) (Coughlan, 2014; Cardaci et al., 2012).

There are known different activators of AMPK with diverse mechanisms of action and pharmacological effects (Hardie, 2016). Although the enzyme was discovered in the late 1980s, details of its activation acting under various metabolic conditions are known only partially. Cell membrane permeable adenosine analog AICAR (5-aminoimidazole-4-carboxamide ribonucleoside) is converted to AMP analogue and binds to the $\gamma$ subunit of AMPK at the same sites as AMP and mimics its effects. Other known allosteric activator A-769662 binds directly to the AMPK $\beta$ subunit at sites distinct from the AMP binding sites (Scott et al., 2014). Many of the activators already known are natural plant products or their derivatives. Among them is also the anti-diabetic drug metformin, which exerts its beneficial effects by decreasing the mitochondrial membrane potential, reducing the 
ATP level and increasing the cellular AMP (Cardaci et al., 2012). Its ability to inhibit mitochondrial Complex I activity and disturb cell respiration results in increase of the activity of AMPK protein through its phosphorylation by LKB1 kinase (Viollet et al., 2012).

Over the last few years more than 100 different natural products have been shown to activate AMPK. The majority of them are products derived of plants used in traditional Asian medicine (Hardie, 2016). Part of them are active as crude polyphenolic extracts and their detailed characterization in terms of constituents and mechanisms of action has not been performed yet. However, further (more advanced) studies on AMPK activating plant extracts seem to be reasonable because they may identify some direct AMPK activators more efficient than metformin and/or with fewer side effects.

Japanese quince (Chaenomeles japonica L., family Rosaceae) is one of the Chaenomeles species native to China, Tibet and Japan (Du et al., 2013). Quince fruit have been traditionally used as the medicinal herb source for $M u$ gua component in the treatment of rheumatoid arthritis, hepatitis or asthma (Du et al., 2013). High content of polyphenols, triterpens, vitamin C, organic acids, pectins, fiber and pleasant flavor makes Japanese quince fruit an interesting raw material for food components like juice, wine, liqueur, puree or jam (Tarko et al., 2014). In our previous study we identified Japanese quince (Chaenomeles japonica L., JQ) fruit polyphenolic extract as a strong in vitro $\alpha$-amylase inhibitor with ability of slowing glucose absorption from digestive tract (Zakłos-Szyda et al., 2015). We also revealed cytoprotective abilities of JQ extract against chemically induced oxidative stress in pancreas beta cells. Moreover, we found that it inhibits protein tyrosine phosphatase 1B (PTP1B), known as the major negative regulator in insulin and leptin signaling. Taking into account that these fruits are a rich source of polyphenolic compounds (mainly catechins and procyanidin oligomers) possessing numerous biological activities (Strugała et al, 2016; Tarko et al., 2014; Bahadoran et al., 2013; Lewandowska et al., 2013; Gorlach et al., 2011; Stręk et al., 2007), we hypothesized that JQ extract can also activate AMPK. Recent reports evidenced black soybean seed coat and grape seed procyanidins as the agents responsible for AMPK activation and glucose uptake in mice and rats (Yamashita et al., 2016; Crescenti et al., 2015; Kurimoto et al., 2013). However, to the best of our knowledge, there are no earlier reports on Japanese quince polyphenols influencing glucose metabolism, thus the aim of the study was to test JQ effect on the AMPK activation. Because liver plays an important role in glucose homeostasis maintenance thus in the study presented we checked the preparation's influence on hepatocytes. The scarce availability of primary human hepatocytes isolated from fresh human liver samples and their limited life span influenced our usage of human originated hepatoma HepG2 cell line as the cellular model. HepG2 cells display many of the genotypic features of normal liver cells and due to their immortalization are often used for in vitro studies (Gerets et al., 2012).

In this report we studied the influence of the JQ extract on phosphorylated AMPK level, but in order to explain potential anti-diabetic mechanism of JQ preparation we also assessed effects of this extract on hepatic glucose uptake, gluconeogenesis, glycogen synthesis, as well as its influence on the expression of genes involved in glucose metabolism regulation (i.e. AMPK, GLUT4, PEPCK, G6P). These analyses allowed us to propose mechanism by which the JQ extract not only activates AMPK but also influences other aspects of carbohydrate metabolism in HepG2 cells cultured under normal, nonmetabolically changed and hyperglycemic conditions.

\section{MATERIALS AND METHODS}

Materials. All reagents used in our study were special-grade commercial products purchased from Sigma-Aldrich (Saint Louis, MO) unless otherwise stated. All cell culture reagents were obtained from Life Technologies (Carlsbad, USA). Tissue culture plastics were supplied by Greiner Bio-One GmbH (Frickenhausen, Austria). All the experimental measurements, if not stated otherwise, were performed using the Synergy 2 BioTekMicroplate Reader.

Japanese quince polyphenol extraction. Extraction of polyphenolic compounds from Japanese quince (JQ) fruits and polyphenols content analysis were performed according to the procedure described previously (Zakłos-Szyda et al., 2015; Stręk et al., 2007). Briefly, homogenized fruits were extracted three times with $70 \%$ aqueous acetone solution (in the ratio $1: 10 \mathrm{w} / \mathrm{v}$ ). The pooled extracts were centrifuged at $1500 \mathrm{~g}$ for 10 min, filtered through Munktell filter AB, concentrated at $40^{\circ} \mathrm{C}$ on vacuum rotary evaporator (Buchi, Switzerland) to remove the acetone and then the aqueous phase was freeze dried. Samples were stored at $-20^{\circ} \mathrm{C}$ before used in analytical and biological activity assays. The calculated yield of extraction was $8.82 \%$. The HPLC method was used for quantitative and qualitative analysis of the components present in the JQ extract (Table 1). The results were presented as $\mathrm{mg}$ of phenolic compounds per $\mathrm{g}$ of freeze dried preparation.

Cell Culture. Human hepatoma HepG2 cell line was purchased from Leibniz Institute DSMZ - German Collection of Microorganisms and Cell Cultures (Leibniz, Germany). HepG2 cells were grown in RPMI 1640 with $10 \%$ fetal bovine serum (FBS, Invitrogen) medium supplemented with $100 \mathrm{U} / \mathrm{mL}$ penicillin, $100 \mu \mathrm{g} / \mathrm{mL}$ streptomycin and $25 \mu \mathrm{g} / \mathrm{ml}$ amphotericin B. Presented medium formulation with $11 \mathrm{mM}$ glucose corresponds to nonmetabolically changed culture conditions. To induce hyperglycemic conditions 24 hours after seeding cells were treated with medium supplemented with glucose to the final concentration $25 \mathrm{mM}$ for selected incubation time (Węłowska et al., 2015; Zang et al., 2004). The cells were maintained at $37^{\circ} \mathrm{C}$ in a humidified incubator containing $5 \% \mathrm{CO}_{2}$ and $95 \%$ air.

Cell viability and proliferation assay. Cells were seeded into 96-well plates at $10^{4}$ cells per well in complete medium and grown for $20 \mathrm{~h}$, then incubated in the presence of the studied $50 \%$ ethanolic extract diluted in RPMI culture medium for either $24 \mathrm{~h}$. Cell viability was quantified with PrestoBlue reagent according to the manufacturer's instructions by measuring the fluorescent signal at F530/590 nm (Excitation/Emission). The obtained fluorescence values were used to calculate cell viability expressed as the percentage of the viability of the untreated control cells (cells treated with equal volume of the vehicle instead of the preparation). To evaluate the protective effect of the JQ preparations against oxidative stress, cells were preincubated for 20 hours with the JQ extract used at the $\mathrm{IC}_{0}$ concentration. Then, to induce the oxidative stress conditions $500 \mu \mathrm{M}$ tert-butylhydroperoxide (t-BOOH) was added for $2 \mathrm{~h}$ in the presence of serum-free RPMI medium and the cells viability was measured. However, in the described experiment apart from wells with control cells $\left(F_{\text {contr }}\right)$ and wells with cells treated with JQ and t-BOOH $\left(F_{\text {treated }}\right)$ blank wells 
Table 1. Chemical composition of Japanese quince polyphenolic extract.

\begin{tabular}{|c|c|c|c|c|c|c|c|c|}
\hline & \multicolumn{5}{|c|}{ Flavanols and hydroxybenzoic acids ${ }^{1}$} & \multirow{2}{*}{$\begin{array}{l}\text { Hydroxycin- } \\
\text { namic acids }\end{array}$} & \multirow{2}{*}{ Flavonols ${ }^{3}$} & \multirow{2}{*}{$\begin{array}{l}\text { Anthocy- } \\
\text { anins }{ }^{4}\end{array}$} \\
\hline \multirow{4}{*}{$\begin{array}{l}\text { Phenolic com- } \\
\text { pounds (mg/g } \\
\text { of freeze dried } \\
\text { preparation) }\end{array}$} & $374.43 \pm 10.6$ & & & & & & & \\
\hline & $(+)$ catechin & (-)epicatechin & EGCG & procyanidin B1 & procyanidin $\mathrm{C} 1$ & \multirow{2}{*}{$96.95 \pm 4.55$} & \multirow{2}{*}{$18.48 \pm 2.59$} & \multirow{2}{*}{$\begin{array}{l}\text { not } \\
\text { detected }\end{array}$} \\
\hline & 154.10 & 29.70 & 27.72 & 99.32 & 89.26 & & & \\
\hline & total & 489.85 & & & & & & \\
\hline
\end{tabular}

Phenolic profiles were determined using a high-performance liquid chromatography system. Values are means \pm standard deviations. ${ }^{1}$ Determined at $280 \mathrm{~nm}$ as gallic acid equivalents; hydroxybenzoic acids. ${ }^{2 D}$ Determined at $320 \mathrm{~nm}$ as chlorogenic acid equivalents; ${ }^{3}$ Determined at $360 \mathrm{~nm}$ as rutin equivalents. ${ }^{4}$ Determined at $520 \mathrm{~nm}$ as cyanidin 3-glucoside equivalents.

with media $\left(F_{\text {blank }}\right)$ and t-BOOH only $\left(F_{\text {blanktBOOH }}\right)$ were also analyzed. Thus, the final values described as cytoprotective effect of JQ on the cell viability were calculated as:

$100 \% \times\left(\mathrm{F}_{\text {treated }}-\mathrm{F}_{\text {blank }} \mathrm{BOOH}\right) /\left(\mathrm{F}_{\text {contr }}-\mathrm{F}_{\text {blank }}\right)=$ cell viability [\%]

Cell proliferation was evaluated with CyQUANT Direct Cell Proliferation Assay according to the manufacturer's instructions by measuring the fluorescent signal at F485/528 nm.

Detection of intracellular reactive oxygen species. To determine the effect of the JQ extract on the intracellular generation of ROS the DCFH-DA assay was performed. After incubating the cells for $20 \mathrm{~h}$ with the extract, they were washed with PBS and loaded with the DCFH-DA dye at a final concentration of $1 \mu \mathrm{M}$ in serum-free medium for 40 minutes. Then, the cells were washed twice with PBS and fluorescent signal at F485/528 nm was measured. In the described experiment apart from wells with control cells $\left(\mathrm{F}_{\text {contr }}\right)$ and wells with cells treated with JQ $\left(\mathrm{F}_{\text {treated }}\right)$ also blank wells with media and vehicle $\left(\mathrm{F}_{\text {blank }}\right)$ and preparation $\left(\mathrm{F}_{\text {blankprep }}\right)$ were analysed. Thus the final values were calculated as:

$100 \% \times\left(\mathrm{F}_{\text {treated }}-\mathrm{F}_{\text {blankprep }} \mathrm{BOOH}\right) /\left(\mathrm{F}_{\text {contr }}-\mathrm{F}_{\text {blank }}\right)=$

ROS production $[\%]$

As the positive control of oxidative stress inducer $500 \mu \mathrm{M}$ t-BOOH was used.

Glucose uptake. Cellular glucose uptake was quantified with 2-NBDG assay using a microplate reader. After incubating the cells for $24 \mathrm{~h}$ with the JQ extract (with $11 \mathrm{mM}$ or $25 \mathrm{mM}$ glucose, respectively) $150 \mu \mathrm{M}$ $2-N B D G$ was added in the glucose-free medium. After 1 $\mathrm{h}$ of incubation cells were washed twice with serum- and glucose-free medium and fluorescent signal at F485/530 $\mathrm{nm}$ was measured immediately.

Glucose production assay. HepG2 cells were seeded into microplate in complete medium and grown for 20 $\mathrm{h}$, then treated for $24 \mathrm{~h}$ in serum-free medium in the presence of the investigated extract diluted in RPMI culture medium. Then, the medium was replaced with glucose production buffer consisting of glucose-free RPMI without phenol red supplemented with $20 \mathrm{mM}$ sodium lactate and $2 \mathrm{mM}$ sodium pyruvate. After $3 \mathrm{~h}$ of incubation the medium was collected and glucose concentration was assessed using a colorimetric glucose assay kit (Glucose (GO) Assay Kit (GAGO-20), Sigma-Aldrich) with absorbance measured at $540 \mathrm{~nm}$. The readings were normalized to the total protein content determined from the whole-cell lysates with Bradford method.

Determination of glycogen content. Glycogen content was determined with glycogen colorimetric assay kit from Sigma-Aldrich. The treated cells were homogenized in distilled water on ice, boiled for 5 minutes to inactivate enzymes, centrifuged at $13000 \times g$ for $5 \mathrm{~min}$ and treated with hydrolysis buffer. Later, according to the manufacturers procedure, master reaction mix was added and after $30 \mathrm{~min}$ the absorbance at $570 \mathrm{~nm}$ was read. The readings were normalized to the total protein content determined from the whole-cell lysates with Bradford method.

Western blot. After the treatment cells were lysed with M-PER Mammalian Protein Extraction Reagent (ThermoFisher) with Halt proteases inhibitor. Equal aliquots $(20 \mu \mathrm{g})$ of the protein samples were separated by 4-12\% SDS-PAGE, transferred to nitrocellulose membranes (BioRad) and blocked with 5\% BSA in PBST buffer. Membranes were incubated with rabbit $\beta$-actin and $\mathrm{p}$-AMPK antibodies (Cell Signaling) at $4{ }^{\circ} \mathrm{C}$ overnight, after which they were incubated with horseradish peroxidase-conjugated mouse anti-rabbit secondary antibody for $1 \mathrm{~h}$ at room temperature. Western blots were developed using SuperSignal ${ }^{\text {TM }}$ West Pico Chemiluminescent Substrate (Thermo Scientific) and quantified by densitometry.

AMPK activation. PAMPK level was analyzed by EnzyFluoTM AMPK Phosphorylation Assay Kit (BioAssay Systems). HepG2cells $\left(3 \times 10^{4}\right.$ cells per well $)$ were seeded into 96-well plate in complete medium and incubated overnight, then starved for another $24 \mathrm{~h}$ in the serum-free medium with $11.1 \mathrm{mM}$ or medium with 25 $\mathrm{mM}$ glucose and treated with the tested JQ preparation for another $24 \mathrm{~h}$. Finally, ELISA determination of phosphorylated AMPK Thr172 in whole cells (normalized to the total protein content) according to the manufacturer's instructions was performed.

Measurement of ATP production. After HepG2 cells treatment the intracellular ATP level was quantified with CellTiter-Glo Luminescent Cell Viability Assay kit according to the manufacturer's instructions (Promega, Madison, WI).

Measurement of mitochondrial membrane potential. The mitochondrial membrane potential was assayed with JC-1 probe. After treatments with the studied compounds the medium was changed and JC-1 (1 $\mu \mathrm{g} / \mathrm{mL})$ was added for $20 \mathrm{~min}$. Then, the cells were washed with serum-free medium and fluorescent signal at F485/590 nm was measured. As a known mitochondrial uncoupler CCCP (carbonyl cyanide 3-chlorophenylhydrazone) was used at $50 \mu \mathrm{M}$ concentration (Julian et al., 2005).

Apoptosis detection. Apoptosis was measured by Cell Death Detection ELISA Plus (Roche Diagnostics) according to manufacturer's instructions. After treatments with the compounds cells were lysed and histone-complexed DNA fragments (mono- and oligonucleosomes) present in the cytoplasmic fraction were quantified with immunoreagent complex. DNA-histone complex served as the positive control. Following incubation and washes, the colorimetric solution was added and after adding the stop solution the colorimetric signal was measured at 405 and $490 \mathrm{~nm}$. 
A

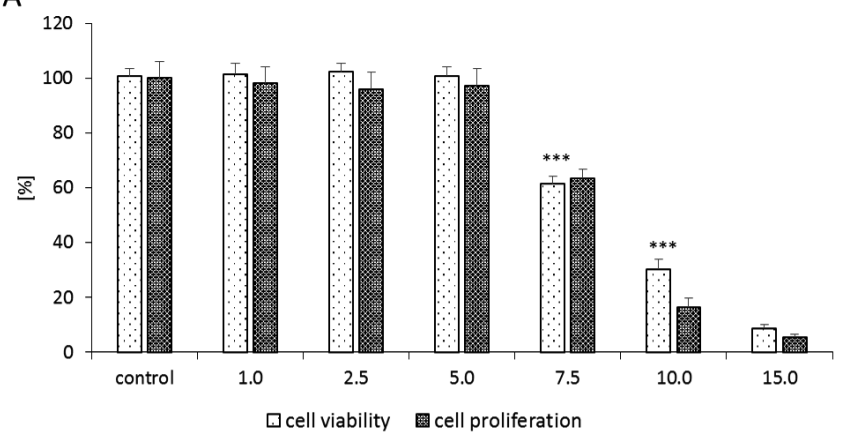

B

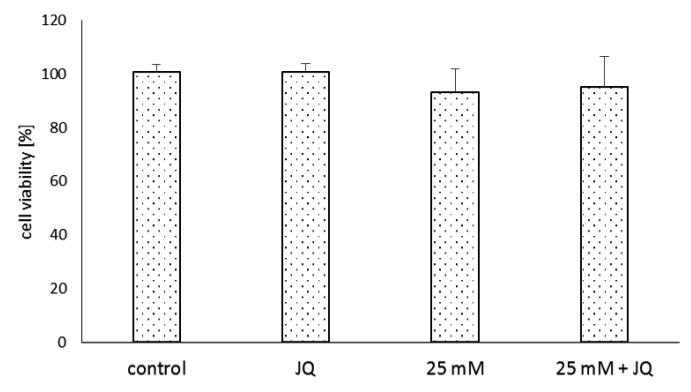

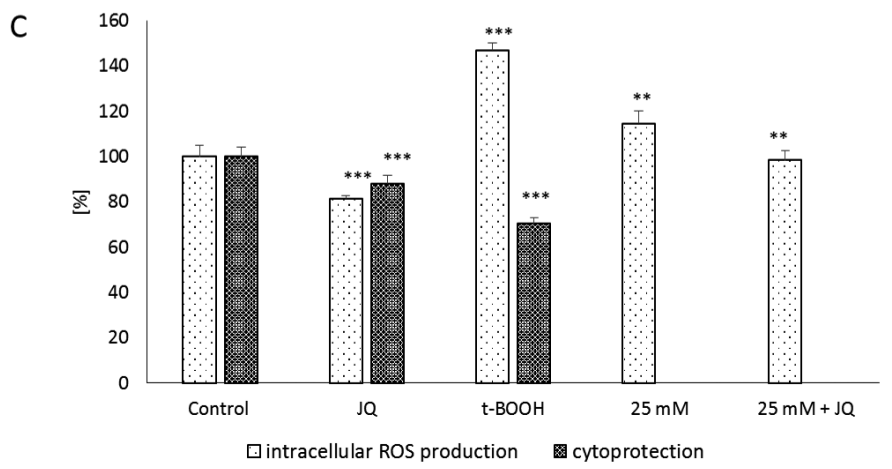

Figure 1. The effect of JQ polyphenols ( $\mathrm{mg}$ of freeze dried preparation $/ \mathrm{mL}$ ) on metabolic activity (analyzed by PrestoBlue assay) and proliferation (analyzed by CyQuant assay) of HepG2 cell line after $24 \mathrm{~h}$ treatment (A). The influence of elevated glucose concentration $(25 \mathrm{mM})$ and JQ $(5 \mathrm{mg} / \mathrm{mL})$ on the HepG2 cells viability (compared to the control cells cultured with $11 \mathrm{mM}$ glucose) (B). The effects of JQ $(5 \mathrm{mg} / \mathrm{mL})$ and t-BOOH $(500 \mu \mathrm{M})$ on intracellular ROS generation (analyzed by DCFH-DA assay) and its cytoprotective activity (analyzed by PrestoBlue assay) in HepG2 cell line after $20 \mathrm{~h}$ treatment compared to the control cells cultured with 11 mM glucose (C).

Cells were cultured in standard medium at $11 \mathrm{mM}$ glucose concentration, unless indicated otherwise. Control cells were not exposed to any compound but the vehicle; values are means \pm standard deviations from at least three independent experiments; statistical significance was calculated versus control cells (untreated) ${ }^{*} p<0.05,{ }^{* *} p<0.01,{ }^{* * *} p<0.001$.

Gene expression analysis. Total RNA was extracted from HepG2 cell culture using RNeasy ${ }^{\circledR}$ Mini Kit (QIAGEN, Venlo, Netherlands) and purified with Amplification Grade DNase I (Sigma-Aldrich). RNA samples were reverse transcribed with RT2 First Strand Kit (SABioscences, Frederick, MD, USA). The human HepG2 gene expression analysis was performed with SABioscience microplates with SYBR Green-optimized primer assays for chosen genes listed in Table 2. Real time RT-PCR was carried out using SYBR ${ }^{\circledR}$ Greenbased RT2 qPCR Master Mix (SABioscences) on a BioRad CFX96 qPCR System (Hercules, Bio-Rad, CA, USA). Complementary DNA representing 6 ng of total RNA per sample was subjected to 40 cycles of PCR amplification. Samples were first incubated at $95^{\circ} \mathrm{C}$ for $15 \mathrm{~s}$, then at $60^{\circ} \mathrm{C}$ for $30 \mathrm{~s}$, and finally at $72^{\circ} \mathrm{C}$ for 30 s. To exclude non-specific products and primer-dimers, after the cycling protocol, a melting curve analysis was performed by maintaining the temperature at $55^{\circ} \mathrm{C}$ for $2 \mathrm{~s}$, followed by a gradual temperature increase to $95^{\circ} \mathrm{C}$. Constitutively expressed GAPDH gene was selected as endogenous control to correct potential variation in RNA loading. The threshold cycle $(\mathrm{Ct})$ values for that gene did not change in independently performed experiments. The level of target gene expression level was calculated as $2-\Delta \Delta \mathrm{Ct}$, where $\Delta \Delta \mathrm{Ct}$ $=[\mathrm{Ct}($ target $)-\mathrm{Ct}(\mathrm{GAPDH})]$ sample $-[\mathrm{Ct}($ target $)-$ $\mathrm{Ct}(\mathrm{GAPDH}]$ calibrator.

Statistical analysis. All data were presented as mean \pm S.D. from at least three independent experiments. All obtained results were subjected to statistical analysis. Determination of average values and one-way ANOVA analysis followed by the Dunnett's test were performed using GraphPad prism 4.0 software (GraphPad Software, Inc. La Jolla, USA) at the significance level of ${ }^{*} p \leq 0.05$, ${ }^{* *} p \leq 0.01,{ }^{* * *} p \leq 0.001$.

\section{RESULTS}

\section{Effect of JQ on cell viability, proliferation and ROS generation}

We first studied the effects of different JQ extract concentrations $(1.0-15.0 \mathrm{mg} / \mathrm{mL})$ on HepG2 cells metabolic activity and proliferation. The JQ influence on viability and proliferation of the studied cells was concentration-dependent (Fig. 1A). $5.0 \mathrm{mg} / \mathrm{mL}$ concentration of the JQ extract was identified as the highest non-cytotoxic concentration $\left(\mathrm{IC}_{0}\right)$ and used in all further experiments performed at normal $(11 \mathrm{mM})$ and elevated glucose concentration $(25 \mathrm{mM})$ in the culture medium. The accuracy of the selected dose was confirmed by cell viability study which revealed that medium with $25 \mathrm{mM}$ glucose did not exacerbate JQ toxic activity on cells (94-96\% viability) (Fig. 1B).

Experimental data presented in Fig. 1A confirmed that the $\mathrm{IC}_{0}$ concentration also did not influenced cell growth indicating no impairment of the cell proliferative machinery. Our previous studies carried out with 
Table 2. The names of selected genes associated with carbohydrate metabolism in HepG2 cells subjected to real time RT-PCR analysis and the effect of JQ on the expression of genes associated with carbohydrate metabolism in HepG2 cells cultured under standard and hyperglycemic conditions.

\begin{tabular}{|c|c|c|c|c|}
\hline \multirow[t]{2}{*}{ Gene symbol (full name) } & \multirow[t]{2}{*}{ Reference sequence } & \multicolumn{2}{|c|}{$\begin{array}{l}\text { mRNA expression level (fold) } \\
\text { vs control } 1\end{array}$} & \multirow{2}{*}{$\begin{array}{l}\text { mRNA expression level } \\
\text { (fold) vs control }{ }^{2}\end{array}$} \\
\hline & & $11 \mathrm{mM}$ glucose $+\mathrm{JQ}$ & $25 \mathrm{mM}$ glucose & \\
\hline GLUT4 (glucose transporter 4) & NM_001042 & $1.62 \pm 0.21^{*}$ & $0.96 \pm 0.19$ & $0.98 \pm 0.31$ \\
\hline GLUT2 (glucose transporter 2) & NM_000340 & $0.95 \pm 0.29$ & $1.12 \pm 0.10$ & $2.14 \pm 0.16 \#$ \\
\hline $\begin{array}{l}\text { PEPCK (phosphoenolpyruvate carboxyki- } \\
\text { nase) }\end{array}$ & NM_002591 & $0.56 \pm 0.04^{*}$ & $2.10 \pm 0.21^{*}$ & $0.82 \pm 0.23 \#$ \\
\hline G6P (glucose-6-phosphatase) & NM_000151 & $1.12 \pm 0.18$ & $1.95 \pm 0.29^{*}$ & $1.12 \pm 0.09$ \\
\hline $\begin{array}{l}\text { PGC-1a (peroxisome proliferator-activated } \\
\text { receptor gamma, coactivator } 1 \text { alpha) }\end{array}$ & NM_013261 & $0.68 \pm 0.15^{*}$ & $0.89 \pm 0.19$ & $0.71 \pm 0.15$ \\
\hline FOXO1 (forkhead box G1) & NM_005249 & $0.66 \pm 0.13^{*}$ & $0.97 \pm 0.21$ & $0.82 \pm 0.16$ \\
\hline GYS2 (glycogen synthase 2 (liver)) & NM_021957 & $1.08 \pm 0.21$ & $0.44 \pm 0.12^{*}$ & $0.81 \pm 0.21$ \\
\hline GSK3A (glycogen synthase kinase 3 alpha) & NM_019884 & $0.50 \pm 0.25$ & $1.15 \pm 0.09$ & $0.78 \pm 0.14$ \\
\hline IRS-1 (insulin receptor substrate 1) & NM_005544 & $1.14 \pm 0.27$ & $0.75 \pm 0.12$ & $1.21 \pm 0.35$ \\
\hline IRS-2 (insulin receptor substrate 2 ) & NM_003749 & $2.08 \pm 0.15^{*}$ & $0.66 \pm 0.21$ & $0.95 \pm 0.29$ \\
\hline PTP1B (protein tyrosine phosphatase 1B) & NM_002827 & $0.79 \pm 0.09^{*}$ & $1.35 \pm 0.10$ & $1.07 \pm 0.36$ \\
\hline $\begin{array}{l}\text { AMPKa } 1 \text { (protein kinase, AMP-activated, } \\
\text { alpha } 1 \text { catalytic } 1 \text { non-catalytic subunit) }\end{array}$ & NM_006251 & $1.09 \pm 0.12$ & $0.89 \pm 0.20$ & $1.01 \pm 0.22$ \\
\hline $\begin{array}{l}\text { AAKG2 (protein kinase, AMP-activated, } \\
\text { gamma } 2 \text { non-catalytic subunit) }\end{array}$ & NM_016203 & $0.88 \pm 0.09$ & $1.11 \pm 0.11$ & $0.98 \pm 0.17$ \\
\hline $\begin{array}{l}\text { AMPKb (protein kinase, AMP-activated, } \\
\text { beta } 1 \text { non-catalytic subunit) }\end{array}$ & NM_006253 & $1.04 \pm 0.07$ & $1.02 \pm 0.15$ & $0.89 \pm 0.21$ \\
\hline
\end{tabular}

1HepG2 cells cultured under normal conditions (in medium with $11 \mathrm{mM}$ glucose) were exposed to JQ preparation (5 mg/mL) for $24 \mathrm{~h}$; control cells were not exposed to JQ. ${ }^{2} \mathrm{HepG} 2$ cells cultured under normal conditions were exposed to JQ preparation (5 mg/mL) for $24 \mathrm{~h}$, and then treated with hyperglycemic conditions (in medium with $25 \mathrm{mM}$ glucose) in the JQ presence for additional 24 h; control cells were exposed to 25 mM glucose, but not exposed to JQ preparation. mRNA expression levels were detected by RT-qPCR using GADPH (glyceraldehyde-3-phosphate dehydrogenase) as internal control and calculated as $2-\Delta \Delta \mathrm{Ct}$, where $\Delta \Delta \mathrm{Ct}=[\mathrm{Ct}$ (target) $-\mathrm{Ct}(\mathrm{GAPDH})]$ sample $-[\mathrm{Ct}(\mathrm{target})-\mathrm{Ct}(\mathrm{GAPDH}$. Data represent the means \pm standard deviations $\left(\mathrm{n} \geq 3\right.$ ); ${ }^{*} p<0.05$ vs control ${ }^{1}$ (cells cultured in media with $11 \mathrm{mM}$ glucose) or \#p<0.05 vs control ${ }^{2}$ (cells cultured in media with $25 \mathrm{mM}$ glucose).

murine insulinoma $\beta$ TC-3 cells allowed to estimate the $\mathrm{IC}_{0}$ value of polyphenolic extract from Japanese quince fruits as ca. $6 \mathrm{mg} / \mathrm{mL}$ and this value is comparable to the one obtained for the HepG2 cells. Thus the selected doses (5-6 $\mathrm{mg} / \mathrm{mL}$ ) seemed to be not harmful to cells of different tissue origin (Zakłos-Szyda et al., 2015). However, incubation of HepG2 cells with higher doses of the JQ extract $(7.5 \mathrm{mg} / \mathrm{mL}$ and $10.0 \mathrm{mg} / \mathrm{mL}$ ) caused, respectively, $40 \%$ and nearly $80 \%$ decrease of the cell viability and proliferation.

The effect of JQ extract on the intracellular reactive oxygen species production was shown in Fig. 1C. As compared to the control, t-BOOH decreased the cell viability almost by $30 \%$ and significantly increased the intracellular ROS production (by nearly 50\%). Cells pre-incubation with the JQ extract reduced t-BOOH induced oxidative stress by nearly $20 \%$, as well as decreased intracellular ROS level by 20\% (comparing to the cells treated with the vehicle only). Thus, cells pre-incubation with the preparation resulted in their protection against t-BOOH induced cytotoxicity. Further studies revealed that HepG2 cells incubation with $25 \mathrm{mM}$ glucose for $24 \mathrm{~h}$ increased the level of intracellularly generated ROS by $15 \%$ in comparison to the cells cultured under normal conditions $(11 \mathrm{mM}$ glucose). JQ pretreatment effectively prevented the ROS production induced by high glucose lowering it to level observed in cells cultured in the medium with $11 \mathrm{mM}$ glucose.

\section{Effect of JQ on intracellular ATP level, mitochondrial membrane potential and AMPK activation}

Due to the fact that AMPK acts as an energy sensor, we analyzed influence of the JQ extract on cellular ATP production. After HepG2 cells treatment with the JQ the ATP level was reduced by almost $15 \%$ (Fig. 2A), thus we investigated the effect of the JQ preparation on mitochondrial membrane potential. Our experiments showed that the JQ extract reduced mitochondrial membrane potential by nearly 35\% (Fig. 2B). Decrease in mitochondrial potential may result from inhibition of mitochondrial respiration or opening of the mitochondrial permeability transition pore with apoptosis induction. To exclude putative impact of the JQ extract on apoptosis induction we carried out analysis of cytoplasmic monoand oligonucleosomes. Their presence in analyzed samples can indicate apoptosis induced DNA degradation. As shown in Fig. 2C, HepG2 cells treatment with the JQ preparation did not induce significant increase of apoptotic cells. Further investigation revealed that both in cells treated with $25 \mathrm{mM}$ glucose and with additional presence of JQ the ATP levels were lowered by $20 \%$. Furthermore, no significant proapoptotic changes in the cells were observed.

To confirm activation of AMP-activated protein kinase and its involvement in hypoglycemic activity of the JQ extract, we estimated the levels of phosphorylated Thr172 residue in AMPK catalytic $\alpha$ subunit (Fig. 3A-B). Indeed, we found that under nonmetabolically changed 
A

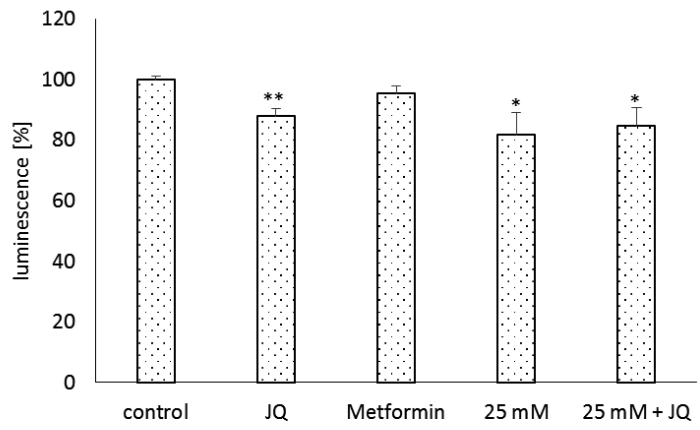

B

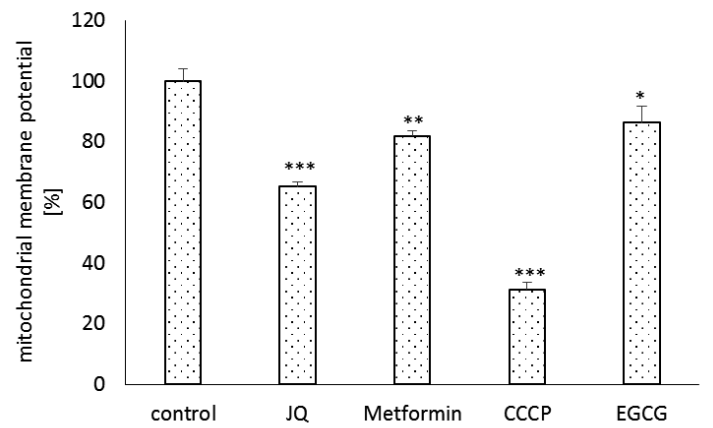

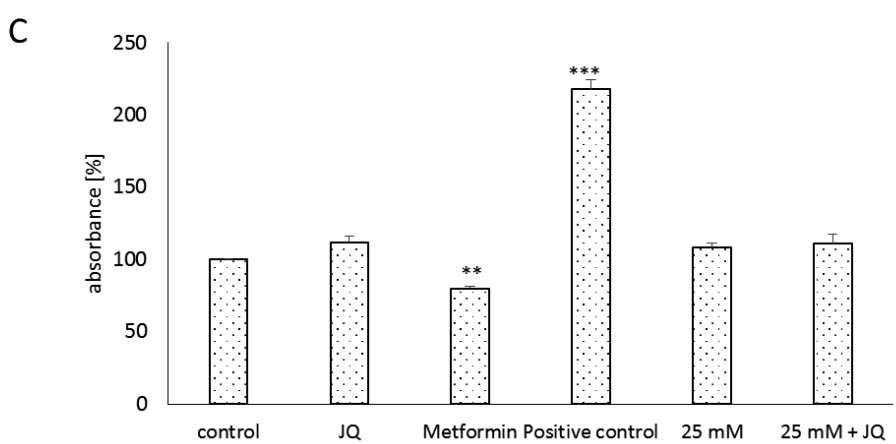

Figure 2. The effect of JQ $(5 \mathrm{mg} / \mathrm{mL})$ and metformin $(2 \mathrm{mM}) 24 \mathrm{~h}$ treatment on ATP level was determined by ATP luminescent assay kit $(A)$. The effect of JQ $(5 \mathrm{mg} / \mathrm{mL})$, EGCG $(5 \mu \mathrm{M})$ and metformin $(2 \mathrm{mM}) 24 \mathrm{~h}$ treatment on mitochondrial membrane potential was determined with JC-1 probe (B); as a positive control depolarization compound CCCP $(50 \mu \mathrm{M})$ was used. The effects of JQ $(5 \mathrm{mg} / \mathrm{mL})$ and metformin ( $2 \mathrm{mM}) 24 \mathrm{~h}$ treatment on apoptosis induction (C) in HepG2 cells were analyzed by apoptosis detection kit.

Control cells were not exposed to any compound but the vehicle. Cells were cultured in medium with $11 \mathrm{mM}$ glucose or in medium with elevated glucose concentration (stated as $25 \mathrm{mM}$ ). Values are means \pm standard deviations from at least three independent experiments; statistical significance was calculated versus control cells (untreated) ${ }^{*} p<0.05,{ }^{* *} p<0.01,{ }^{* * *} p<0.001$.

conditions the JQ extract increased $\mathrm{pAMPK} \alpha^{\mathrm{Thr} 172}$ amount by at least $35 \%$ as compared to the control. The presence of phosphorylated AMPK was confirmed by western blot analysis, where the most spectacular effect was observed for metformin used as positive control, but the JQ extract also induced significant phosphorylation and activation of the AMP-dependent protein kinase. However, analysis of mRNA levels revealed that the JQ extract only slightly influenced the expression of mRNA encoding $A M P K$ subunits $(\alpha, \beta$ and $\gamma)$ in HepG2 (Table 2). These results suggested that elevated AMPK $\alpha$ Thr172 phosphorylation is a consequence of reduced mitochondrial membrane potential and elevated AMP/ATP ratio rather than of the increased AMPK protein level.

Elevation of supplemented glucose concentration to $25 \mathrm{mM}$ significantly influenced HepG2 cells metabolism. We found that hyperglycemia decreased AMPK $\alpha^{\mathrm{Thr} 172}$ phosphorylation by $25 \%$. Nevertheless, JQ cells pretreatment increased the pAMPK $\alpha^{\text {Thr172 }}$ level to the value slightly lower than obtained for the preparation alone. Interestingly, the change in cell culture conditions did not affect the level of $A M P K$ subunits genes expression.

\section{JQ polyphenols modulate glucose production, glucose uptake and glycogen content}

To explore potential hypoglycemic effect of the JQ polyphenolic extract first we checked its influence on gluconeogenesis in HepG2 cells cultured under metabolically unchanged conditions. As reference compounds in these experiments we used metformin $(2 \mathrm{mM})$ and epigallocatechingallate (EGCG) (at the $\mathrm{IC}_{0} 5 \mu \mathrm{M}$ ) known, respectively, as AMPK activator and hepatic gluconeo- genesis inhibitor (Viollet et al., 2012; Collins et al., 2007). As it was shown in Fig. 4A the JQ extract decreased the hepatic glucose release by $20 \%$, whereas metformin and EGCG suppressed it by $30 \%$ and $7 \%$, respectively.

Then, we tested the JQ preparation effect on expression of two major gluconeogenesis regulators: PEPCK converting oxaloacetate to phosphoenolpyruvate and G6Pase responsible for hydrolysis of glucose-6-phosphate to glucose. Both of these enzymes are regulated at the transcriptional level by forkhead transcription factor (FOXO1) and peroxisome proliferative activated receptor-gamma co-activator 1 (PGC-1alpha) (O-Sullivan et al., 2015; Jitrapakdee, 2012). As it was shown in Table 2, the JQ extract did not influence G6Pase mRNA expression level, but caused 2-fold decrease in the level of mRNA corresponding to the gene encoding PEPCK. Moreover, exposure of HepG2 cells to JQ preparation resulted in 30\% decrease of FOXO1 and PGC-1alpha mRNA levels suggesting a functional link between lower the transcription of the genes encoding these two transcription factors and the level of gluconeogenic enzymes like PEPCK. Although decrease in mRNA level estimated in our experiments for FOXO1, PGC-1alpha and PEPCK genes was not very prominent, these data indicated possible mechanism of the JQ extract-mediated inhibition of hepatic gluconeogenesis and glucose release.

Further studies showed that HepG2 treatment with the JQ preparation resulted in $25 \%$ increase of glucose fluorescent analogue 2-NBDG uptake (Fig. 4B). Quantitative PCR analysis revealed that JQ pretreat- 

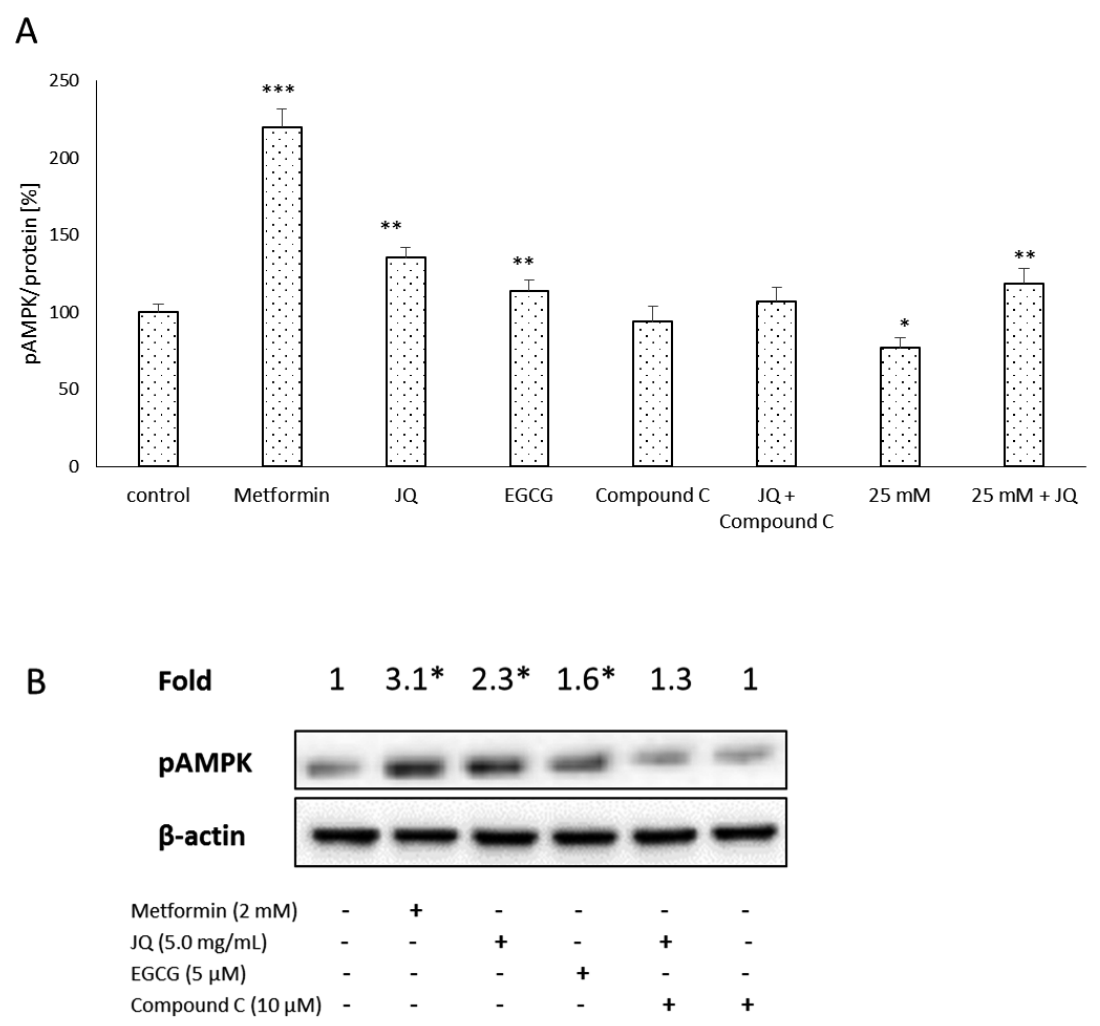

Figure 3. The effects of JQ $(5 \mathrm{mg} / \mathrm{mL})$, EGCG $(5 \mu \mathrm{M})$ and metformin $(2 \mathrm{mM}) 24 \mathrm{~h}$ treatment on pAMPKThr172 level in HepG2 cells detected with ELISA assay kit (as indicated cells were cultured in medium with $11 \mathrm{mM}$ glucose or $25 \mathrm{mM}$ glucose) (A); cells were preincubated with compound C $(10 \mu \mathrm{M})$ for 1 hour before JQ treatment. Phosphorylated AMPK level with beta-actin as loading control was analyzed by western blot (B).

Bands of western blot representative experiment with percentage data of $\mathrm{pAMPK} / \beta$-actin relative to the control condition; values are means \pm standard deviations from at least three independent experiments; statistical significance was calculated versus control cells (untreated) ${ }^{*} p<0.05,{ }^{* *} p<0.01,{ }^{* * *} p<0.001$.

ment of HepG2 cells did not influenced the expression of the gene encoding glucose transporter GLUT2 (Table 2), but increased by $60 \%$ the level of mRNA corresponding to the gene encoding glucose transporter GLUT4. It is well known that glucose uptake requires translocation of GLUT4 transporter from intracellular space to the plasma membrane. This process can be enhanced by AMPK-signaling pathways by procyanidins (Yamashita et al., 2012). Our results indicated that JQ polyphenolic compounds can increase GLUT4 gene expression to some extent. Furthermore, cells incubation with combination of JQ and insulin $(100 \mathrm{nM})$, which is known to suppress gluconeogenesis and stimulate glucose uptake, did not extend the effect observed for the JQ extract used alone, which suggests that the JQ preparation might stimulate glucose uptake through insulin-signaling pathway. EGCG turned out to be less effective as the activator of the 2-NBDG uptake than the JQ extract. This observation can be explained according to the report by Ueda et al., who observed that non-gallate type catechins (like epicatechin) stimulate glucose uptake efficiently while gallate type catechins (like EGCG) are less effective activators of this process (Ueda et al., 2010).

It is known that the glucose taken by the cells is at least partially converted into glycogen. Our analysis showed that after pretreatment of HepG2 cells with the JQ preparation the intracellular glycogen content increased by almost $40 \%$ (Fig. 4A). Glycogen synthesis is catalyzed by liver glycogen synthase (GYS2) which is negatively regulated via phosphorylation by glycogen synthase kinase-3 (GSK-3) (von Wilamowitz-Moellendorff et al., 2013). We found that the JQ extract did not influence GYS 2 mRNA level, but reduced twice the mRNA level of its inhibitor GSK-3 (Table 2). In addition, the level of mRNA corresponding to the IRS2gene was doubled, mRNA for IRS1 was unchanged, while the level of mRNA corresponding to protein tyrosine phosphatase 1B (PTP1B) was decreased by $20-30 \%$. These changes in mRNA levels can result in, respectively, decreased level of PTP1B, increased level of IRS2 and reduced level of GSK-3. Insufficient level of the latter enzyme (GSK-3) and reduced phosphorylation of its substrate (GYS2) can finally lead to higher activity of liver glycogen synthase and increased content of glycogen.

Finally, we elucidated the preventive JQ effect on HepG2 cells cultured under hyperglycemic conditions in the presence of $25 \mathrm{mM}$ glucose. As shown in Fig. 4A, the level of glucose release was 2-fold greater than that observed for untreated cells cultured under standard conditions. This result was accompanied by doubled expression of PEPCK and G6Pase (Table 2). However, these effects were repressed by cells pretreatment with JQ preparation, which was able to down-regulate not only the expression of these genes, but also of FOXO1 and PGC-1alpha. Further experiments revealed that culturing the cells at high glucose level decreased the cellular glycogen amount by $30 \%$, which was accompanied by a double reduction of GYS2 level, though without the influence on GSK3A. In line with these results are decreased levels of IRS1 and IRS2, and increased PTP1B at 
A

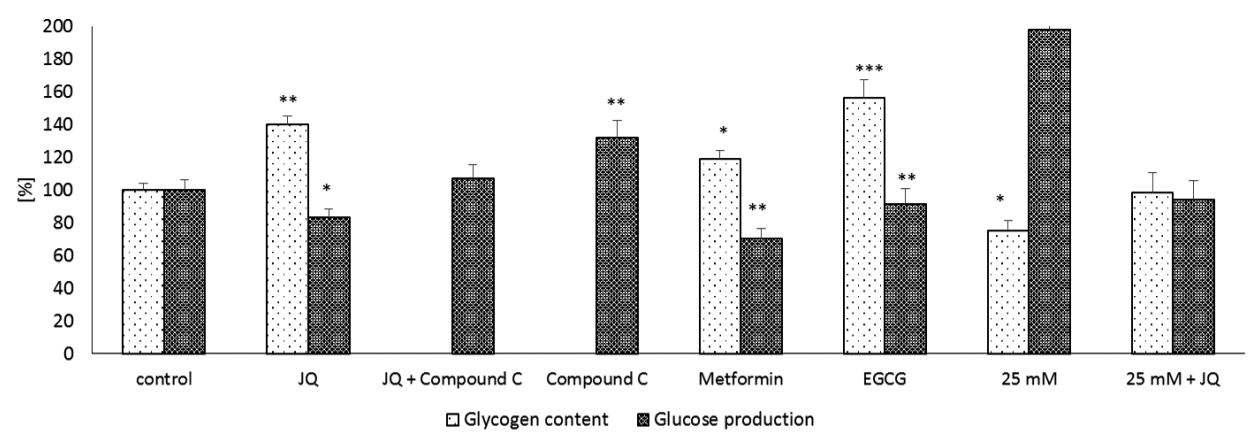

B

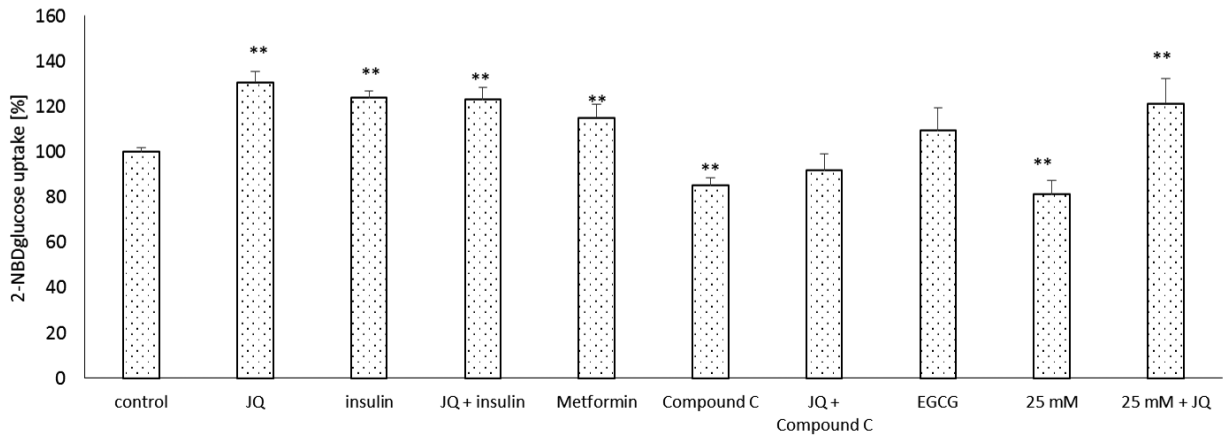

Figure 4. The effects of JQ ( $5 \mathrm{mg} / \mathrm{mL})$, metformin $(2 \mathrm{mM})$, compound $\mathrm{C}(10 \mu \mathrm{M})$ and EGCG $(5 \mu \mathrm{M})$ treatments on glycogen content and glucose production in HepG2 cells were analyzed respectively by glycogen and glucose assay kits; cells were incubated with studied compounds for $24 \mathrm{~h}$, with exception of compound C (1 hour) (A). The effect of JQ, compound C, metformin and EGCG $24 \mathrm{~h}$ pretreatment on 2-NBDG (150 $\mu \mathrm{M}, 1$ hour) uptake in HepG2 cells; 10 minutes before the measurement of fluorescence intensity 100 $\mathrm{nM}$ insulin was added to the cells without any compound or treated with JQ (B).

Cell were cultured in presence of $11 \mathrm{mM}$ glucose, unless elevated glucose level was indicated ( $25 \mathrm{mM})$. Control cells were not exposed to any compound but the vehicle; values are means \pm standard deviations from at least three independent experiments; statistical significance was calculated versus control cells (untreated) ${ }^{*} p<0.05,{ }^{* *} p<0.01,{ }^{* * *} p<0.001$.

high glucose concentration. After incubation with JQ the levels of abovementioned genes were restored to the values corresponding to normal glucose level as compared to cells cultured under hyperglycemic conditions. Simultaneously, $25 \mathrm{mM}$ glucose reduced the cellular glucose uptake by approximately $20 \%$ (Fig. 4B). Pretreatment with JQ increased 2-NBDG uptake by almost $40 \%$ to the level comparable to the cells treated with preparation only. Therefore, gene expressions of glucose transporters GLUT2 and GLUT4 were determined. Comparing to the untreated cells the mRNA level of GLUT2 was not influenced significantly by addition of high glucose, though it increased two times after addition of JQ and high glucose. The preparation did not exert significant effect on GLUT4 expression.

\section{JQ involvement in AMPK signaling}

To determine the role of Japanese quince polyphenols in AMPK activation, and also in modulation of glucose production and uptake, before incubation with JQ we pretreated cells with $10 \mu \mathrm{M}$ compound $\mathrm{C}$ for 1 hour. Compound C, known also as dorsomorphin, is widely used in studies of AMPK signaling as its cell-permeable inhibitor (Lu et al., 2014). As can be seen in Figs. 3 and 4 the cells treatment with this inhibitor displayed decrease of pAMPK $\alpha^{\text {Thr172 }}$ level and glucose uptake, as well as increased glucose production. Interestingly, cells incubation simultaneously with the compound C and JQ partially increased AMPK phosphorylation and lowered glucose production. One can suggest that the JQ treatment partially recovered $\mathrm{pAMPK} \alpha^{\mathrm{Th} 172}$ level, however, that hypothesis needs further confirmation by analysis of the AMPK downstream substrates phosphorylation levels.

\section{DISCUSSION}

Japanese quince fruits are a rich source of biologically active polyphenols and the major phenolic compounds are flavan-3-ols including catechin, epicatechin and procyanidin oligomers (Zakłos-Szyda et al., 2015; Du et al., 2013; Gorlach et al., 2011). Because of its anti-inflammatory, antibacterial, antioxidant and immunoregulatory properties Chaenomeles japonica plant has been widely used in traditional Chinese medicine. Recently it was also identified as cancer chemopreventive agent with proliferation, invasiveness and angiogenesis inhibition effect (Lewandowska et al. 2013; Gorlach et al., 2011). Moreover, our previous results identified Japanese quince polyphenols as potent inhibitors of carbohydrates digestive enzymes (Zakłos-Szyda et al., 2015). In this report we demonstrated that JQ polyphenols exhibit cytoprotective activities and regulate glucose metabolism during in vitro studies in HepG2 cells. Due to the fact that hyperglycemia leads to the increased production of reactive oxygen species and to the cellular damage progression, most of the studies presented here were carried out on HepG2 cells cultured under nonmetabolically changed and hyperglycemic (at elevated glucose concentration) conditions, which finally allowed us to verify the JQ activity in normal and altered glucose concentrations. As compared to the normal culture conditions the elevated glucose concentration caused a significant increase in ROS generation in HepG2 cells. When it comes to outcomes obtained for cytoprotective actions, the oxidative stress inducer t-BOOH was used, whose toxic properties result from production of tertbutoxyl, peroxyl, alkoxyl and methyl radicals catalyzing lipid peroxidation, DNA strand breaks and alteration in intracellular calcium homeostasis 
with glutathione and protein thiol depletion (Goncalves et al, 2013). We demonstrated that in all studied cases the preparation decreased intracellular ROS levels. The lowering of intracellular ROS generation and cytoprotective effects observed for the JQ extract can be explained according to the recent paper by Strugała and coworkers who postulated that JQ extract from Chaenomeles speciosa fruits induces a considerable increase of the packing order of membrane lipids polar heads and slight decrease in mobility of lipid acyl chains. These effects could increase rigidity of lipid membrane which, in turn, could reduce oxidative reactions kinetics and propagation of lipid peroxidation (Strugała et al., 2016). The ability of flavonoids to reach all the regions of the membrane bilayer, as it was indicated in other studies (Scheidt et al., 2004), due to their scavenging potential towards free radical cations, could protect the cellular membrane against oxidation. In this line that protective effect could be deepened by donating hydrogen compound, quenching singlet oxygen and preventing lipid peroxidation. Thus, despite the fact that hydrophobic t-BOOH easily crosses the cell membrane and generates free radicals inside the cell, JQ polyphenolic components could be able to hinder the diffusion and spreading of the new free radicals generated by tert-butyl hydroperoxide. On the other hand, it is known that cocoa polyphenols are able to evoke significant recovery of GSH, the most powerful and abundant intracellular antioxidant, from its oxidized form (Martin et al., 2013). Additionally, interactions of polyphenols with specific proteins and plasma membrane compartments responsible for signal transduction (known as lipid rafts) activate the production of the nuclear transcription factor $\mathrm{Nrf2}$, which is involved in protection against oxidative stress and result in inhibition of oxidative damage of the cellular components (Zheng et al., 2012; Tarahovsky et al., 2014).

It is known that liver is the major site for synthesis, storage and redistribution of carbohydrates. The main of them, glucose, is produced via gluconeogenesis or glycogenolysis and then can be supplied to or removed from the circulation. The major glucose transporter present in the liver cells is GLUT2 involved in bi-directional fluxes of glucose and some polyphenolic compounds, like EGCG and resveratrol, are able to elevate its expression (Snoussi et al., 2014; Karim et al., 2012; Vetterli et al., 2011). In the present study the increase of glucose uptake after JQ treatment was detected, albeit dependently on the presence of hyperglycemic conditions different influence on glucose transporters was observed. In case of standard conditions no effects on the GLUT2 mRNA levels were noticed. Unexpectedly, we observed elevated level of GLUT4 mRNA. This protein is expressed mainly in insulin responsive muscle and fat cells, and in the response to activation of insulin signaling pathway is rapidly translocated from the intracellular vesicles to the plasma membrane (Doan et al., 2015). Phenolic compounds influence on hepatic GLUT4 level and/or activity has been so far scarcely evaluated, but recently Doan et al. reported results of in vivo studies, where elevated hepatic GLUT4 mRNA levels were observed after the treatment of mice with gallic acid (2015). Independently, Ashida's team observed GLUT4 translocation after treatment of mice with dimer to tetramer procyanidins from black soybean seed coat and this effect was accompanied by AMPK activation (Yamashita et al., 2016). Other studies proved that the EGCG activation of AMPK was mediated by the $\mathrm{Ca}^{2+} /$ calmodulin-dependent protein kinase kinase (CaMKK) dependent on ROS production (Collins et al., 2007). Taking into account our results one can suggest that activation of AMPK can be stimulated by oligomeric procyanidins, like procyanidins B1 and $\mathrm{C} 1$, which are present in the JQ extract in significant amounts (see Table 1).

While glucose-stimulated upregulation of mice hepatic expression of GLUT2 transporter was shown by Im and coworkers (2005), in our studies only after JQ addition to $25 \mathrm{mM}$ glucose we detected elevation of GLUT-2 expression and glucose uptake, as well as gluconeogenesis process inhibition. Our findings are in accordance with the report by Zhou et al., who observed an increase of GLUT2 expression in hepatocytes isolated from T2D patients after treatment with metformin, which is used in anti-diabetic therapy (2016). Metformin potential to activate AMPK is very well known, however, due to many pleiotropic effects observed the mechanism of its antihyperglycemic action has not been elucidated so far (Viollet et al., 2012). It is known that metformin does not directly activate neither LKB1 nor AMPK, but exerts its beneficial effects in part by perturbing mitochondrial function due to decrease of mitochondrial membrane potential and reduction of ATP production (Cardaci et al., 2012). Its ability to inhibit mitochondrial complex I activity and disturb cell respiration increases activity of AMPK protein through its phosphorylation by LKB1 kinase (Viollet et al., 2012). In this line our outcomes could suggest that JQ extract resembles metformin mechanism of action and contributes to AMPK activation due to the change of mitochondrial membrane potential. As the result, one can expect a decrease of the mitochondrial enzymes activity, decrease in the ATP, and finally AMPK $\alpha^{\text {Thr172 }}$ phosphorylation induced by falling energy status. Additional confirmation of our "similarity of actions" hypothesis results from strong influence of the JQ preparation on mitochondrial enzymes activity, cellular viability and proliferation. Similarly to metformin, JQ preparation enhanced glucose uptake upon hyperglycemia by GLUT2 level elevation (Fig. 4B). However, in case of metformin several different mechanisms were suggested to explain its hypoglycemic actions. First of all, it was proposed that due to its apolar hydrocarbon side-chain metformin is able to nonspecifically modify membranes, including mitochondrial ones, through its binding to hydrophobic structures (Viollet et al., 2012). Other studies demonstrated that metformin is able to improve glucose uptake and sensitivity to insulin by increasing membrane fluidity (Weijers, 2012; Freisleben et al., 1992). It probably results from inhibition of advance glycation end products (AGE) creation, which could damage cellular components and induce oxidative stress. Furthermore, according to Dai and coworkers (2014) in hepatoprotective effect of metformin the enhancement of catalase activity is involved due to the compound direct interaction with enzyme via hydrogen bonds formation. These data may suggest other nonspecific impact of JQ preparation on different metabolic pathways, which should be further evaluated.

Activation of AMPK precedes GLUT4 translocation and glucose uptake, but it also negatively regulates the transcription of genes encoding gluconeogenic enzymes like PEPCK and G6Pase (Hardie, 2014). We showed that HepG2 cells treatment with the JQ influenced PEPCK expression level and glucose production, and similar effect was observed also in cells treated with 25 $\mathrm{mM}$ glucose. We suggest that this effects caused by the JQ were partly AMPK-dependent, because HepG2 cells pretreatment with compound C abolished the JQ ability to inhibit gluconeogenesis and stimulate glucose uptake 


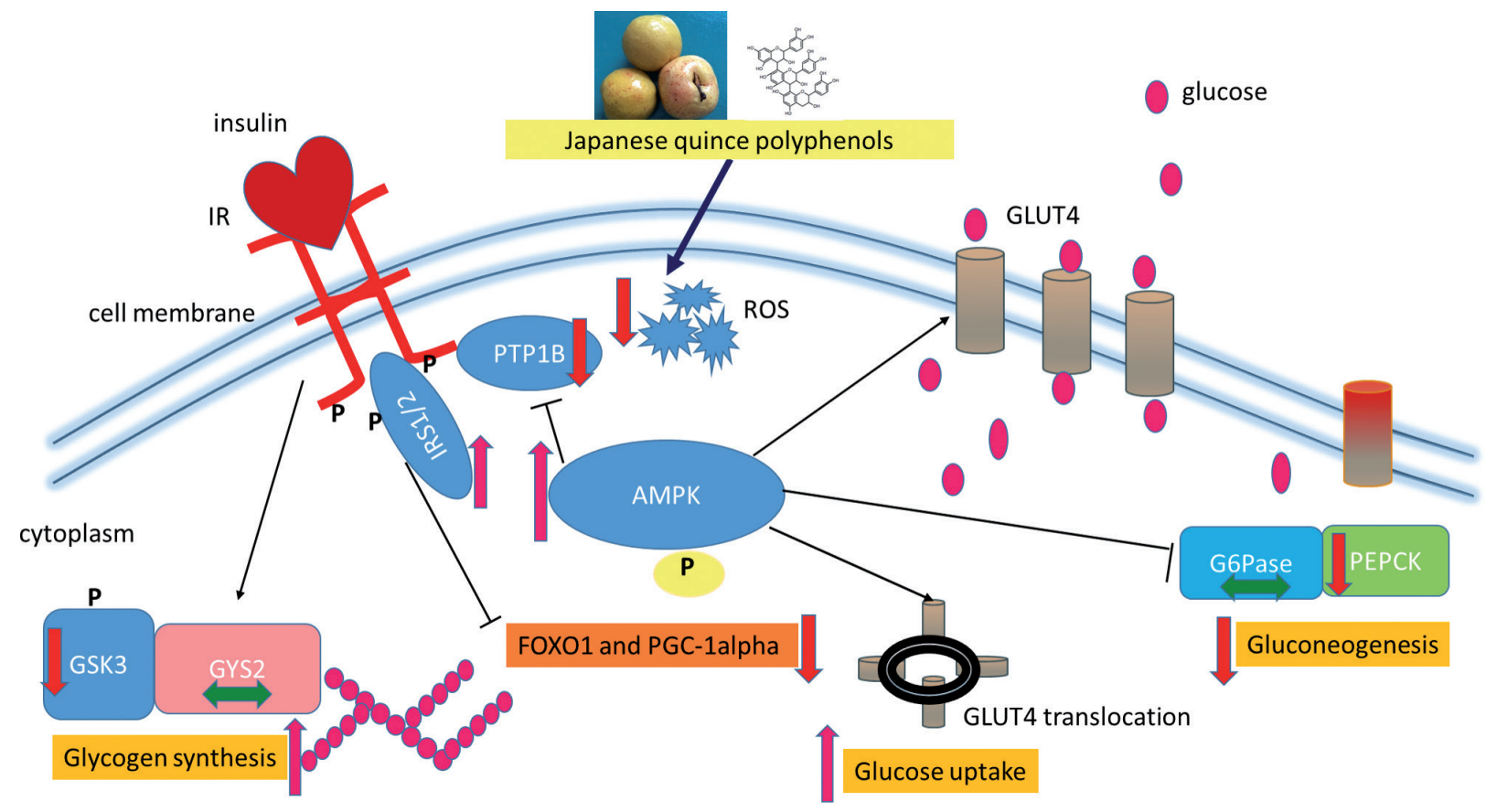

Figure 5. Schematic of proposed influence of Japanese quince polyphenols on glucose metabolism in HepG2 cells. JQ polyphenolic extract activates AMPK phosphorylation, promotes glucose uptake and glycogen synthesis, whilst also decreases ROS generation and gluconeogenesis. Arrows indicate activation, while perpendicular lines indicate inhibition of processes.

under normal glucose level (Figure 4), but this hypothesis needs further studies. The JQ polyphenols were also able to increase glycogen synthesis and that finding is consistent with the results obtained for HepG2 cells treated under hyperglycemic conditions with EGCG and green tea polyphenols (Kim et al., 2013).

Our analysis of gene expression was focused also on IRS1/2 and PTP1B genes. Insulin binding to the IR leads to tyrosine phosphorylation of insulin receptor substrates (IRS) with subsequent activation of PI3K/Akt and MAP kinase pathways. Akt stimulation further leads to the inhibition of GSK-3 and through FOXO1 phosphorylation to decreased PEPCK and G6Pase expression. In hepatic insulin resistance distortion of insulin stimulated signal transduction results from decrease of IR and IRS1/2 expression and inhibition of their phosphorylation (Boucher et al., 2014). After the JQ treatment IRS2 mRNA was elevated but, which is more important, the decreased level of PTP1B mRNA was observed. Contrary to the data presented above, hyperglycemic conditions decreased IRS1/2 levels with simultaneous elevation of PTP1B, however, JQ pretreatment resulted in restoration of glucose homeostasis in the explored area. These are in agreement with our previous studies which identified the JQ extract polyphenols as PTP1B enzyme inhibitors (Zakłos-Szyda et al., 2015). Protein tyrosine phosphatase 1B dephosphorylates the IR and IRS, disturbing signal transduction from insulin receptor, thus, inhibitors of this phosphatase have a major role in modulating insulin sensitivity and carbohydrate metabolism. This may mean that Japanese quince polyphenols stimulate glucose uptake and improve hepatic insulin sensitivity by decreasing PTP1B expression and are useful in prediabetes treatment.

Together, these studies highlight the potential role of Japanese quince polyphenolic extract in regulation of glucose metabolism in human liver HepG2 cell line through its direct effects on hepatic gene expression and metabolism (Fig. 5). In particular, JQ activates AMPK involved in gluconeogenesis inhibition and decreases hepatic glucose production. Lowering blood glucose level by JQ is associated with its abilities to increase glucose uptake and glycogen synthesis. Due to the fact that non-diabetic, but elevated blood glucose levels are strongly predictive of a high risk of developing type 2 diabetes, the results obtained for Japanese quince polyphenols make it promising as a phytomedicine or diet component suitable for prevention of prediabetes, type 2 diabetes and metabolic syndrome. Our studies proposed potential molecular mechanism accounting for hypoglycemic activity of Japanese quince polyphenols but its properties should be further evaluated.

\section{Authors contribution}

M.Z-S. carried out in vitro experiments, was involved in study design, data analysis and wrote the manuscript; N.P. took part in carrying out in vitro experiments.

\section{Acknowledgements}

The authors thank Professor Maria Koziołkiewicz for her encouragement and critical comments.

The authors would like to thank the Unknown Reviewer for his very valuable comments which allowed them to enrich presented work.

\section{Conflict of interest}

The authors declare no conflict of interest.

\section{Financial acknowledgements}

This research was financially supported in part by grants from National Science Centre (Grants No. 3407/B/P01/2011/40, UMO-2011/01/B/NZ9/04699) 
and The National Centre for Research and Development (Grant No. PBS1/B8/7/2013).

\section{REFERENCES}

Bahadoran Z, Mirmiran P, Azizi F (2013) Dietary polyphenols as potential nutraceuticals in management of diabetes: a review. $J$ Diabetes Metab Disorders Disorders 12: 43. doi: 10.1186/2251-6581-12-43

Boucher J, Kleinridders A, Kahn CR (2014) Insulin receptor signaling in normal and insulin-resistant states. Cold Spring Harb Perspect Biol 6: a009191. doi: 10.1101/cshperspect.a009191

Brereton MF, Rohm M, Ashcroft FM (2016) $\beta$-Cell dysfunction in diabetes: a crisis of identity? Diabetes Obes Metab 18 (Suppl 1): 102109. doi: $10.1111 /$ dom. 12732

Cardaci S, Filomeni G, Ciriolo MR (2012) Redox implications of AMPK-mediated signal transduction beyond energetic clues. I Cell Science 125: 2115-2125.doi: 10.1242/jcs.095216

Collins QF, Liu HY, Pi J, Liu Z, Quon MJ, Cao W (2007) Epigallocatechin-3-gallate (EGCG) a green tea polyphenol suppresses hepatic gluconeogenesis through 5'-AMP-activated protein kinase. J Biol Chem 282: 30143-30149

Coughlan KA, Valentine RJ, Ruderman NB, Saha AK (2014) AMPK activation: a therapeutic target for type 2 diabetes? Diabetes Met Syndrome Obesity 7: 241-253. doi: 10.2147/DMSO.S43731

Crescenti A, del Bas JM, Arola-Arnal A, Oms-Oliu G, Arola L, Caimari A (2015) Grape seed procyanidins administered at physiological doses to rats during pregnancy and lactation promote lipid oxidation and up-regulate AMPK in the muscle of male offspring in adulthood. J Nutr Biochem 26: 912-920. doi: 10.1016/j.jnutbio.2015.03.003

Dai J, Liu M, Ai Q, Lin L, Wu K, Deng X, Jing Y, Jia M, Wan J, Zhang L (2014) Involvement of catalase in the protective benefits of metformin in mice with oxidative liver injury. Chem Biol Interact un 216: 34-42. doi: 10.1016/j.cbi.2014.03.013

Doan KV, Ko CM, Kinyua AW, Yang DJ, Choi Y-H, Oh IY, Nguyen NM, Ko A, Choi JW, Jeong Y, Jung MH, Cho WG, Xu S, Park KS, Park WJ, Choi SY, Kim HS, Moh SH, Kim KW (2015) Gallic acid regulates body weight and glucose homeostasis through AMPK activation. Endocrinol 156: 157-168. doi: 10.1210/en.2014-1354

Du H, Wu J, Li H (2013) Polyphenols and triterpenes from Chaenomeles fruits: Chemical analysis and antioxidant activities assessment. Food Chem 141: 4260-4268. doi: 10.1016/j.foodchem.2013.06.109

Freisleben HJ, Rucker TS, Wiernsperger N, Zimmer G (1992) The effects of glucose insulin and metforminon the order parameters of isolated red cellmembranes; an electron paramagnetic resonance spectroscopicstudy. Biochem Pharmacol 43: 1185-1194

Gerets HHJ, Tilmant K, Gerin B, Chanteux H, Depelchin O, Dhalluin S, Atienzar FA (2012) Characterization of primary human hepatocytes HepG2 cellsand HepaRG cells at the mRNA level and CYP activityin response to inducers and their predictivity for the detectionof human hepatotoxins. Cell Biol Toxicol 28: 69-87. doi: 10.1007/s10565-011-9208-4

Goncalves G, Gregorio I, Catarino TA, Martel F (2013) The effect of oxidative stress upon the intestinal epithelial uptake of butyrate. Eur J Pharmacol 699: 88-100. http: //dx.doi.org/10.1016/j.ejphar.2012.11.029

Gorlach S, Wagner W, Podsędek A, Szewczyk K, Koziołkiewicz M, Dastych J (2011) Procyanidins from Japanese quince (Chaenomeles japonica) fruit induce apoptosis in human colon cancer Caco-2 cells in a degree of polymerization-dependent manner. Nutr Cancer 63: 1348-1360. doi: 10.1080/01635581.2011.608480

Hardie DG (2016) Regulation of AMP-activated protein kinase by natural and synthetic activators. Acta Pharmacol Sin B 6: 1-19. doi: 10.1016/j.apsb.2015.06.002

Hardie DG (2014) AMPK - sensing energy while talking to other signaling pathways. Cell Metab 20: 939-952. doi: 10.1016/j. cmet.2014.09.013

Hardie DG, Carling D, Gamblin SJ (2011) AMP-activated protein kinase: also regulated by ADP? Trends Biochem Sci 36: 470-477.doi: 10.1016/j.tibs.2011.06.004

Hostalek U, Gwilt M, Hildemann S (2015) Therapeutic use of metformin in prediabetes and diabetes prevention. Drugs 75: 1071-1094. doi: 10.1007/s40265-015-0416-8

Im S-S, Kang S-Y, Kim S-Y, Kim H, Kim J-W, Kim K-S, Ahn Y-H (2005) Glucose-stimulated upregulation of GLUT2 gene is mediated by sterol response element-binding protein-1c in the hepatocytes. Diabetes 54: 1684-1691. doi: 10.2337/diabetes.54.6.1684

Jitrapakdee S (2012) Transcription factors and coactivators controlling nutrient and hormonal regulation of hepatic gluconeogenesis. Int J Biochem Cell Biol 44: 33-45. doi: 10.1016/j.biocel.2011.10.001

Julian D, April KL, Patel S, Stein JR, Wohlgemuth SE (2005) Mitochondrial depolarization following hydrogen sulfide exposure in erythrocytes from a sulfide-tolerant marine invertebrate $J$ Exp Biol 208: 4109-4122
Karim S, Adams DH, Lalor PF (2012) Hepatic expression and cellular distribution of the glucose transporter family. World J Gastroenterol 18: 6771-6781. doi: 10.3748/wjg.v18.i46.6771

Kerimi A, Jailani F, Williamson G (2015) Modulation of cellular glucose metabolism in human HepG2 cells by combinations of structurally related flavonoids. Mol Nutr Food Res 59: 894-906. doi: $10.1002 / \mathrm{mnfr} .201400850$

Kim JJY, Tan Y, Xiao L, Sun YL, Qu X (2013) Green Tea Polyphenol Epigallocatechin-3-Gallate enhances glycogen synthesis and inhibits lipogenesis in hepatocytes. Biom Res Int. doi: 10.1155/2013/920128

Kurimoto Y, Shibayama Y, Inoue S, Soga M, Takikawa M, Ito C, Nanba F, Yoshida T, Yamashita Y, Ashida H, Tsuda T (2013) Black soybean seed coat extract ameliorates hyperglycemia and insulin sensitivity via the activation of AMP-activated protein kinase in diabetic mice. I Agric Food Chem 12: 5558-5564. doi: 10.1021/jf401190y

Lewandowska U, Szewczyk K, Owczarek K, Hrabec Z, Podsędek A, Koziołkiewicz M, Hrabec E (2013) Flavanols from Japanese quince (Chaenomeles japonica) fruit inhibit human prostate and breast cancer cell line invasiveness and cause favorable changes in Bax/Bcl-2 mRNA ratio. Nutr Cancer 65: 273-285. doi: 10.1080/01635581.2013.749292

Liu X, Chhipa RR, Nakano I, Dasgupta B (2014) The AMPK inhibitor compound $\mathrm{C}$ is a potent $\mathrm{AMPK}$-independent antiglioma agent. Mol Cancer Ther 13: 596-605. doi: 10.1158/1535-7163.MCT-13-0579

Martín MA, Ramos S, Cordero-Herrero I, Bravo L, Gova L (2013) Cocoa phenolic extract protects pancreatic beta cells against oxidativestress. Nutrients 5: 2955-2968. doi: 10.3390/nu5082955

O-Sullivan IS, Zhang W, Wasserman DH, Liew CW, Liu J, Paik J, DePinho RA, Stolz DB, Kahn CR, Schwartz MW, Unterman TG (2015) FoxO1 integrates direct and indirect effects of insulin on hepatic glucose production and glucose utilization. Nat Commun 6: 7079. doi: 10.1038 /ncomms8079

Scott JW, Ling NM, Issa SMA, Dite TA, O’Brien MT, Chen ZP, Galic S, Langendorf CG, Steinberg GR, Kemp BE, Oakhill JS (2014) Small molecule drug A-769662 and AMP synergistically activate naive AMPK independent of upstream kinase signaling. Chem Biol 21: 619-627. doi: 10.1016/j.chembiol.2014.03.006

Scheidt HA, Pampel A, Nissler L, Gebhardt R, Huster D (2004)Investigation of the membrane localization and distribution offlavonoids by high-resolution magic angle sinning NMR spectroscopy. Bichim Biophys Acta 1663: 97-107. doi: 10.1016/j.bbamem.2004.02.00

Snoussi C, Ducroc R, Hamdaoui MH, Dhaouadi K, Abaidi H, Cluzeaud F, Nazaret C, Le Gall M, Bado A (2014) Green tea decoction improves glucose tolerance and reduces weight gain of rats fed normal and high-fat diet. I Nutr Biochem 25: 557-564. doi: 10.1016/j.jnutbio.2014.01.006

Stręk M, Gorlach S, Podsędek A, Sosnowska D, Koziołkiewicz M, Hrabec Z, Hrabec E (2007) Procyanidin oligomers from Japanese quince (Chaenomeles japonica) fruit inhibit activity of MMP-2 and MMP-9 metalloproteinases. I Agric Food Chem 55: 6447-6452

Strugała P, Cyboran-Mikołajczyk S, Dudra A, Mizgier P, Kucharska AZ, Olejniczak T, Gabrielska J (2016) Biological activity of Japanese quince extract and its interactions with lipids erythrocyte membrane and human albumin. J Membr Biol 249: 393-410. doi: 10.1007/s00232-016-9877-2

Tarahovsky Y, Kim YA, Yagolnik EA, Muzafarov EN (2014) Flavonoid-membrane interactions: Involvement of flavonoid - metal complexes in raft signaling. Biochim Biophys Acta 1838: 1235-1246. doi: 10.1016/j.bbamem.2014.01.021

Tarko T, Duda-Chodak A, Satora P, Sroka P, Pogoń P, Machalica J (2014) Chaenomeles japonica, Cornus mas, Morus nigra fruits characteristics and their processing potential. J Food Sci Technol 51: 3934-3941. doi: 10.1007/s13197-013-0963-5

Ueda M, Furuyashiki T, Yamada K, Aoki Y, Sakane I, Fukuda I, Yoshida K, Ashida H (2010) Tea catechins modulate the glucose transport system in 3T3-L1 adipocytes. Food Funct 1: 167-173. doi: $10.1039 / \mathrm{c} 0$ fo00105h.

Węgłowska E, Szustak M, Gendaszewska-Darmach E (2015) Proangiogenic properties of nucleoside 5'-O-phosphorothioate analogues under hyperglycaemic conditions. Cur Top Med Chem 15: 2464-2474. doi: 10.2174/1568026615666150619142859

World Health Organization 2016 http: //apps.who.int/iris/bitstream/10665/204871/1/ 9789241565257_eng.pdf?ua=1 (accessed 10.01.17)

Vetterli L, Brun T, Giovannoni L, Bosco D, Maechler P (2011) Resveratrol potentiates glucose-stimulated insulin secretion in INS-1E beta-cells and human islets through Sirt1 dependent mechanism. I Biol Chem 286: 6049-6060. doi: 10.1074/jbc.M110.176842

Viollet B, Guigas B, Garcia NS, Leclerc J, Fore M (2012) Cellular and molecular mechanisms of metformin: an overview. Clin Sci (Lond) 122: 253-270. doi: 10.1042/CS20110386

von Wilamowitz-Moellendorff A, Hunter RW, García-Rocha M, Kang L, López-Soldado I, Lantier L, Patel K, Peggie MW, Martínez-Pons C, Voss M, Calbó J, Cohen PT, Wasserman DH, Guinovart JJ, Sakamoto K (2013) Glucose-6-phosphate-mediated activation of liv- 
er glycogen synthase plays a key role in hepatic glycogen synthesis. Diabetes 62: 4070-4082. doi: 10.2337/db13-0880

Weijers RNM (2012) Lipid composition of cell membranes and its relevance in Type 2 Diabetes Mellitus. Curr Diabetes Rev 8: 390-400. doi: 10.2174/157339912802083531

Yamashita Y, Wang L, Nanba F, Ito C, Toda T, Ashida H (2016) Procyanidin promotes translocation of glucose transporter 4 in muscle of mice through activation of insulin and AMPK signaling pathways. PLoS One 11: e0161704. doi: 10.1371/journal.pone.0161704

Yamashita Y, Okabe M, Natsume M, Ashida H (2012) Cacao liquor procyanidin extract improves glucose tolerance by enhancing GLUT4 translocation and glucose uptake in skeletal muscle. J Nutr Sci 1: e2. doi: 10.1017/jns.2012.2

Zakłos-Szyda M, Majewska I, Redzynia M, Koziołkiewicz M (2015) Antidiabetic effect of polyphenolic extracts from selected edible plants as $\alpha$-amylase $\alpha$-glucosidase and PTP1B inhibitors and $\beta$ pancreatic cells cytoprotective agents - a comparative study. Curr Top Med Chem 15: 2431-2444. doi: 10.2174/15680266156661506191430 51

Zang M, Zuccollo A, Hou X, Nagata D, Walsh K, Herscovitz H, Brecher P, Ruderman NB, Cohen RA (2004) AMP-activated protein kinase is required for the lipid-lowering effect of metformin in insulin-resistant human HepG2 cells. J Biol Chem 279: 47898-47905. doi: 10.1074/jbc.M408149200

Zheng Y, Morris A, SunkaraM, Layne J, Toborek M, Hennig B (2012) Epigallocatechin-gallate stimulates NF-E2-related factor and heme oxygenase-1 via caveolin-1 displacement. J Nutr Biochem 23: 163-168. doi doi: 10.1016/j.jnutbio.2010.12.002

Zhou K, Yee SW, Seiser EL, van Leeuwen N, Tavendale RA, Bennett AJ, Groves CJ, Coleman RL, van der Heijden AA, Beulens JW, de Keyser CE, Zaharenko L, Rotroff DM, Out M, Jablonski KA, Chen L, Javorský M, Židzik J, Levin AM, Williams LK, Dujic T, Semiz S, Kubo M, Chien HC, Maeda S, Witte JS, Wu L, Tkáč I, Kooy A, van Schaik RHN, Stehouwer CDA, Logie L; MetGen Investigators; DPP Investigators; ACCORD Investigators, Sutherland C, Klovins J, Pirags V, Hofman A, Stricker BH, Motsinger-Reif AA, Wagner MJ, Innocenti F, 't Hart LM, Holman RR, McCarthy MI, Hedderson MM, Palmer CNA, Florez JC, Giacomini KM, Pearson ER (2016) Variation in the glucose transporter gene SLC2A2 is associated with glycemic response to metformin. Nat Genet 48: 1055-1059. doi: 10.1038/ng.3632. 